\title{
Disseminated colorectal tumor cells in organs prone to metastasis detected by new double enriched nested-PCR in comparison with recognized assays
}

\author{
MAGDALENA C. KRAUS ${ }^{1}$, ULRICH LINNEMANN ${ }^{2}$ and MARTIN R. BERGER ${ }^{1}$ \\ ${ }^{1}$ Toxicology and Chemotherapy Unit, German Cancer Research Center, D-69120 Heidelberg; \\ ${ }^{2}$ Department of Surgery, Municipal Hospital of Nürnberg, Nürnberg D-90419, Germany
}

Received October 8, 2010; Accepted November 26, 2010

DOI: $10.3892 /$ or.2011.1203

\begin{abstract}
Hypothetically, K-ras mutations can be used as a marker of disseminated tumor cells (DTCs) in patients with K-ras mutated primary carcinoma. This study focused on the development of a useful assay for detecting low numbers of DTCs in potential target tissues of metastatic K-ras codon 12 mutated colorectal cancer. Tumor, liver, lymph node and bone marrow tissues from 46 colorectal carcinoma patients were examined for K-ras codon 12 mutations with a new double enriched nested (DEN)-PCR and the incidence of mutations was compared to those obtained from three established assays. DEN-PCR followed by sequencing found one mutated cell within $10^{7} \mathrm{~K}$-ras codon 12 wild-type cells and was more sensitive than other methods $\left(1: 10^{6}-1: 10^{2}\right)$. Colon carcinomas (26/46) and adenomas (1/3) harbored mutations in K-ras codon 12 . Sixteen of these 27 mutated tumors were found with all assays, two with three methods and one with the two most sensitive assays. In 8 cases, only DEN-PCR identified the K-ras mutation, and thus prevailed over the other methods used $(\mathrm{p}<0.002)$. Eight of 26 patients with K-ras mutated colorectal carcinoma also harbored K-ras mutated DTCs in liver and lymph nodes, respectively, and 4 in bone marrow. For liver and lymph node samples, DTC-mutations were identical to those in the primary carcinoma but those in bone marrow differed from the respective mutation in the primary carcinoma. In conclusion, DEN-PCR is a highly sensitive method for detecting K-ras mutations as marker of early and late tumor cell dissemination in tissues potentially harboring colorectal carcinoma metastases.
\end{abstract}

Correspondence to: Dr Martin R. Berger, Toxicology and Chemotherapy Unit, German Cancer Research Center, INF 280, D-69120 Heidelberg, Germany

E-mail: m.berger@dkfz-heidelberg.de

Key words: K-ras codon 12 mutation, colorectal carcinoma, double enriched nested-PCR, new detection method

\section{Introduction}

Colorectal cancer is one of the leading causes for cancerrelated death worldwide with a high incidence and mortality rate (1). About $41 \%$ of the 529,000 deaths worldwide occur in Western countries. The corresponding estimated survival rates vary from $66 \%$ (United States) to 55\% in Western Europe and decrease considerably to $36 \%$ in Eastern Europe compared to $30 \%$ in India for instance. These differences might be related to the stage of the disease in which colorectal carcinoma is diagnosed, because surgical treatment of UICC stage I colorectal carcinoma is curative in $70-90 \%$, followed by $60-80 \%$ in stage II patients, $50 \%$ in stage III and $5-25 \%$ in stage IV $(2,3)$.

In 2003 , more than $50 \%$ of colorectal cancer cases in the US were ranked as stage II or III. There are controversial opinions regarding adjuvant therapy for stage II patients outside clinical trials (4-6). In a recent study, $27 \%$ out of 718 surgically treated patients with colorectal carcinoma stage II suffered from early recurrence after successful R0 resection and $21 \%$ of 722 patients experienced early recurrence, despite additional chemotherapy (7). Thus, only $6 \%$ of patients with colorectal carcinoma stage II benefited from adjuvant therapy after surgical resection, but $94 \%$ of these patients underwent chemotherapy without any benefit. Obviously it is desirable to treat only those $27 \%$ of colorectal carcinoma stage II patients who likely will show early recurrence after surgical treatment. Hypothetically, these groups of high-risk patients who could benefit from adjuvant therapy are those with undiagnosed minimal residual disease at the time of surgery. Methods and markers are needed to detect disseminated tumor cells, and thus distinguish these patients from those who are cured by surgery alone.

A variety of immunohistochemical and molecular markers have been used to detect circulating epithelial cells (e.g. guanylylcyclase C, cytokeratin 20) and disseminated tumor cells (e.g. K-ras mutations, carcinoembryonic antigen) in organs such as lymph nodes, bone marrow and liver $(5,8,9)$. $\mathrm{K}$-ras mutations are frequent in a wide range of human tumors, ranging from over $90 \%$ in pancreatic cancer to $50 \%$ in colorectal cancer. The genetic alterations in K-ras contribute to the oncogenic potential of mutated tissues (10). The detection of K-ras mutations in organs of potential metastasis might serve as a marker for tumor cell dissemination. 
$\mathrm{K}$-ras is one of the most frequently mutated c-oncogenes in human cancers, especially in colorectal cancer $(11,12)$. It functions as a guanine nucleotide binding protein in signal transduction and its signaling supports increased cell proliferation and enhanced cell survival $(5,13-15)$. Because the functional states of K-ras could be of prognostic and therapeutic value, many studies have focused on examining K-ras mutations in various tissue samples $(8,9,16)$. K-ras codon 12 and 13 mutations are correlated with different traits of tumor cell dissemination, e.g. K-ras codon 12 mutated tumor cells spread significantly more often into the liver than K-ras codon 13 mutated tumor cells, which were found more often in lymph node specimens $(5,13,14,17)$. Furthermore, K-ras codon 12 mutations increase in frequency relative to K-ras codon 13 mutations during tumor progression $(18,19)$. With respect to their relative distribution, K-ras codon 12 mutations prevail over codon 13 mutations (20). Therefore, the assay development detailed in this feasibility study was focused on the more prevalent K-ras codon 12 mutation.

A variety of PCR-methods have been developed to detect K-ras codon 12 point mutations. Limiting factors of these methods are either lack of sufficient sensitivity to detect a low number of mutated cells in a large surplus of wild-type cells (21; Pauli et al, AACR 94th Annual Meeting, abs. $6371,2003)$ or their performance is time-consuming and not manageable within one working day (14).

In the present prospective study, we introduce the double enriched nested-PCR (DEN-PCR) method for detecting low numbers of K-ras codon 12 mutations as markers of DTC in organs prone to metastasis from patients with $\mathrm{K}$-ras codon 12 mutated primary colorectal carcinoma, and compared the incidence of DTC with those resulting from three established assays.

\section{Materials and methods}

Patient samples. Tissue samples originating from 49 consecutive patients who underwent elective surgery for colorectal carcinoma in the municipal hospital of Nürnberg, Germany were entered into this prospective study. After preoperatively obtaining informed consent from the patients and based on the approving decision of the ethics committees, the following tissue samples were collected. Primary tumor tissue (200-500 mg) was taken from a central part of the respective carcinoma. Only non-necrotic tissue was collected. Surgical techniques were based on central lymph dissection for colonic cancer cases (24/49) and total mesorectal dissection for rectal cancer cases (25/49). Bone marrow samples $(2 \mathrm{ml})$, truecut biopsies from macroscopic inconspicuous liver (left and right liver lobes, respectively) and para-aortic lymph node tissue were also taken. All samples were snap-frozen in liquid nitrogen and stored at $-80^{\circ} \mathrm{C}$ until further examination. From a total sample mass of up to $500 \mathrm{mg}$ (tumor tissue), 20-200 mg were subjected to DNA and RNA extraction.

Control cell lines used for detecting $K$-ras codon 12 mutations. Two cell lines, the human leukemia cell line SKW3 and the human colon carcinoma cell line SW620, were used as controls for all PCR techniques. The K-ras codon 12 wild-type SKW3 cell line functioned as negative control, whereas SW620 cells served as positive control for detecting K-ras codon 12 mutations (GGT $\rightarrow$ GAT). SW620 cells were cultured in Leibowitz L15 medium, SKW3 cells in RPMI-1640 medium (both with 10\% FCS, 2 mM L-glutamine) under standard conditions (humidified atmosphere, $5 \% \mathrm{CO}_{2}$, temperature $37^{\circ} \mathrm{C}$ ) and passaged twice weekly to maintain logarithmic growth.

Extraction of DNA. For DNA extraction, tissue samples from colorectal carcinoma patients were subjected to homogenization and lysis using the Qiagen RNA/DNA Kit (Qiagen, Hilden, Germany). Isolated DNA was measured by spectrophotometry.

Detection of K-ras mutations with established PCR-methods Detection of K-ras mutations by RFLP-PCR. The RFLP-PCR consisted of two PCR and two restriction fragment length polymorphism steps and was performed as described before (14).

A $12-\mu 1$ aliquot of each reaction was analyzed by electrophoresis on an $8 \%$ polyacrylamide gel (Roth, Karlsruhe, Germany), stained with ethidium bromide for $3 \mathrm{~min}$ and examined under UV light using a video densitometer (Herolab, Wiesloch, Germany).

Detection of K-ras mutations by REMS-PCR. According to the protocol by Ward et al (22), each PCR reaction contained the thermostable restriction enzyme BstNI, which prevented the amplification of K-ras wild-type amplicons. The diagnostic primers (5BIT: 5'-TATAAACTTGTGGTAGTTGGACCT-3' and 3K2: 5'-CGTCCACAAAATGATTCTGA-3', mismatch base underlined) were added to induce a cleavage site for BstNI. In case of a K-ras wild-type sequence, BstNI restricted the amplicon ( $81 \mathrm{bp}$ ) into fragments of 32 and $49 \mathrm{bp}$. Mutations in codon 12 of K-ras did not undergo cleavage, and thus the mutant amplicon was selectively amplified. In addition, a set of template control primers (5BK38: 5'-GTACACATG AAGCCATCGTATA-3' and 3K39: 5'-CCACTTGTACTA GTATGCCTTAAG-3') was used to amplify a 214-bp DNA sequence in exon $4 \mathrm{~B}$ of the K-ras gene, which was absent in case of poor quality or insufficient amount of DNA template. Enzyme control primers (5BK36: 5'-CTAGAACAGTAG ACACAAACCA-3' and 3K37: 5'-GATTTTGCAGAAA ACAGATC-3') induced a cleavage site in a 130-bp amplicon in exon 3 of K-ras, which was only seen in case of dysfunctional or inactive restriction enzyme BstNI. For each reaction, 100-300 ng template DNA was used, 40 pmol of each diagnostic primer, 2 pmol of each enzyme control primer, 20 pmol of each PCR control primer, deoxynucleotide triphosphate, $4 \mathrm{mmol} / \mathrm{I} \mathrm{Mg}^{2+}$ and $40 \mathrm{U}$ BstNI, $6 \mathrm{U}$ RedTaq polymerase and $5 \mu \mathrm{l}$ buffer $(10 \mathrm{x})$. The total reaction volume $(50 \mu \mathrm{l})$ was subjected to initial denaturation $\left(5 \mathrm{~min}\right.$ at $\left.95^{\circ} \mathrm{C}\right)$ followed by 30 cycles of denaturation $\left(1 \mathrm{~min}\right.$ at $\left.94^{\circ} \mathrm{C}\right)$, annealing $\left(1 \mathrm{~min}\right.$ at $\left.58^{\circ} \mathrm{C}\right)$ and elongation $\left(90 \mathrm{sec}\right.$ at $\left.72^{\circ} \mathrm{C}\right)$. All reactions were analyzed by electrophoresis on an $8 \%$ PAGE-gel as previously described for RFLP-PCR.

Detection of K-ras mutations by real-time PCR and PNAclamping. According to the protocol by Lahr et al (21) real-time PCR was performed with two FRET (fluorescent 


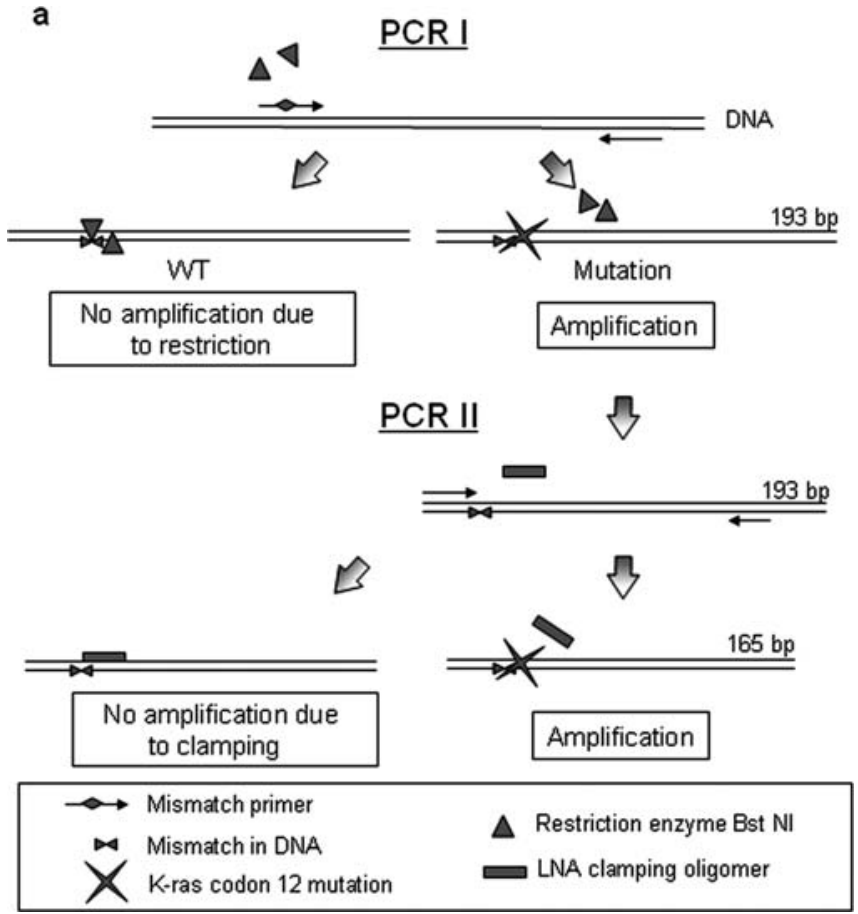

b
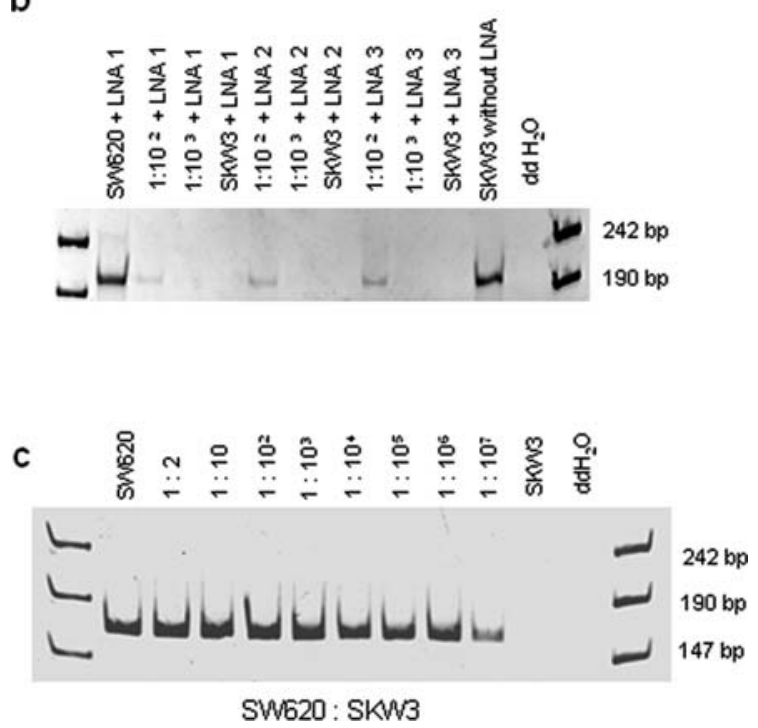

Figure 1. (a) Flow chart of DEN-PCR. In the first PCR step, a primer with a mismatch base pair is used, inducing a restriction site for BstNI. As a result, there is no amplification of amplicons from wild-type DNA due to restriction while those resulting from mutated DNA are amplified. The product of this first PCR is used for the second PCR that makes use of an LNA-clamping oligomer that prevents the wild-type DNA product from amplification while mutated product is amplified. (b) The DEN-PCR was performed with DNA isolated from SW620 (K-ras mutated) and SKW3 (K-ras wild-type) cells as well as dilutions of SW620 in SKW3 cells ranging from 1:102 to 1:103. For inhibition of template from DNA containing wild-type K-ras, LNA oligomers 1, 2 and 3 were added. A band indicating K-ras mutated template was seen for SW620 DNA and, with increasing intensity, for the dilution 1:10 2 of mutated in wild-type cells plus LNA 1, 2 or 3, respectively. The band resulting from SKW3 DNA without LNA oligomers shows the integrity of the K-ras wild-type DNA. (c) The DEN-PCR was performed with DNA isolated from SW620 (K-ras mutated) and SKW3 (K-ras wild-type) as well as dilutions of K-ras mutated SW620 cells and K-ras wild-type SKW3 cells ranging from $1: 2$ to $1: 10^{7}$.

resonance energy transfer) hybridization probes, sensor12 Cys and anchor -12+ (TIB MolBiol, Berlin, Germany) together with components from the Qiagen Real-Time PCR Kit and subjected to cycling in a Roche Light Cycler. Initial denaturation $\left(10 \mathrm{~min}\right.$ at $\left.95^{\circ} \mathrm{C}\right)$ was followed by 30 cycles of denaturation $\left(20 \mathrm{sec}\right.$ at $\left.95^{\circ} \mathrm{C}\right)$, annealing $\left(15 \mathrm{sec}\right.$ at $\left.60^{\circ} \mathrm{C}\right)$ and elongation $\left(15 \mathrm{sec}\right.$ at $\left.72^{\circ} \mathrm{C}\right)$. Each reaction mixture contained both hybridization probes (sensor: 5'-TTGCCTACGCCAC AAGCTCCAA-3' and anchor: 5'-CGTCCACAAAATGA TTCTGAATTAGCTGTATCGTCA-3'; $0.2 \mu \mathrm{M}$ each), two primers (Lux 5': 5'-aagGCCTGCTGAAAATGACTG-3' and Lux 3': 5'-ggtcctgcaccagtaatatgc-3'; $0.3 \mu \mathrm{M}$ each), $3 \mathrm{mM}$ $\mathrm{MgCl}_{2}$ and Light Cycler DNA Master Mix (Qiagen) in a final volume of $20 \mu \mathrm{l}$. The amount of DNA template was 10-20 ng. Each reaction was performed with and without peptide nucleic acid (PNA: 5'-TACGCCACCAGCTCC-3'), a wildtype K-ras oligodeoxynucleotide (NH-oligoDN-CONH) (TIB MolBiol) at $0.7 \mu \mathrm{M}$ to prevent amplification of K-ras wildtype sequences by PNA-clamping. Melting curve analysis conditions were as follows: denaturation $\left(20 \mathrm{sec}\right.$ at $\left.95^{\circ} \mathrm{C}\right)$, hybridization $\left(15 \mathrm{sec}\right.$ at $\left.40^{\circ} \mathrm{C}\right)$ and continuous increase in temperature $\left(0.3^{\circ} \mathrm{C}\right.$ per sec; $\left.40-95^{\circ} \mathrm{C}\right)$. Channel $\mathrm{F} 3$ was used for fluorescence monitoring.

Development of a new method (DEN-PCR) for detecting K-ras codon 12 mutations. The double enriched nested (DEN) PCR method was developed to combine high sensitivity with time efficient performance. To that purpose, two PCR steps with concomitant suppression of K-ras wild-type template formation were consecutively performed. In the first PCR, $\mathrm{K}$-ras wild-type templates were cleaved by the restriction enzyme BstNI, in the second PCR the same target was suppressed by clamping with suited LNA-containing oligonucleotides (Fig. 1a). The resulting K-ras mutated template was as a single band that could be sequenced after simple purification. In detail, the first PCR made use of primers (RepRas 5': 5'-GGCCTGCTGAAAATGACTGAATATAA ACTTGTGGTAGTTGGAㅡㄷㄴ-3' and 3': 5'-GAGAAACC TTTATCTGTATCAAAGAATGGTCCTGCACCAGTAAT ATGC-3', mismatch base underlined) generating a template of $193 \mathrm{bp}$ and introducing a cleavage site for the restriction enzyme BstNI. This enzyme cleaved a K-ras wild-type template into fragments of 148 and $45 \mathrm{bp}$. Forty units of this thermostable enzyme were added to each tube containing the primers RepRas 5' and 3' $(0.2 \mu \mathrm{M}), 1.5 \mathrm{U}$ Red Taq polymerase, dNTP's $(200 \mu \mathrm{M}), 10 \mathrm{x}$ reaction buffer $(50 \mu \mathrm{l})$ and 50-100 ng template DNA. The reaction was run in a volume of $50 \mu 1$ with a thermocycler (DNA engine PTC200, MJ Research, Watertown, MA) according to the following protocol: initial denaturation $\left(4 \mathrm{~min}\right.$ at $95^{\circ} \mathrm{C}$ ) was followed by 30 cycles of denaturation $\left(60 \mathrm{sec}\right.$ at $\left.94^{\circ} \mathrm{C}\right)$, annealing $(30 \mathrm{sec}$ at $\left.53^{\circ} \mathrm{C}\right)$, elongation $\left(60 \mathrm{sec}\right.$ at $\left.72^{\circ} \mathrm{C}\right)$ and final elongation (4 min at $72^{\circ} \mathrm{C}$ ). The resulting product was diluted 1000 -fold in double de-ionized water and used as template for the second PCR step $(1 \mu 1)$. The subsequent PCR made use of the high thermostability of an LNA/DNA oligonucleotide annealing to the wild-type sequence. A mutation in the DNA target sequence reduced the temperature necessary to dissociate the annealed sequences, and thus allowed elongation of the mutated allele. LNA/DNA oligonucleotide (10 pmol) was used for a single reaction, (sequence: 5'-TaC gCc ACC aGg TcC-3'; melting temperature: $85^{\circ} \mathrm{C}$, capital letters indicate 
LNA bases, small letters indicate DNA bases). The nested primers LiCy 5' and 3' (5'-GGCCTGCTGAAAATGACTG AA-3' and 5'-GTCCTGCACCAGTAATATGCA-3'; $0.2 \mu \mathrm{M}$, respectively) were used in this second PCR together with dNTP's $(200 \mu \mathrm{M}), 1.5 \mathrm{U}$ Red Taq polymerase and 10x reaction buffer in a total volume of $50 \mu \mathrm{l}$. Thermocycling was performed according to the following protocol: initial denaturation $\left(4 \mathrm{~min}\right.$ at $\left.95^{\circ} \mathrm{C}\right)$ followed by 30 cycles of denaturation $\left(60 \mathrm{sec}\right.$ at $\left.95^{\circ} \mathrm{C}\right)$, annealing $\left(30 \mathrm{sec}\right.$ at $\left.57^{\circ} \mathrm{C}\right)$, elongation $\left(60 \mathrm{sec}\right.$ at $\left.72^{\circ} \mathrm{C}\right)$ and final elongation $(4 \mathrm{~min}$ at $72^{\circ} \mathrm{C}$ ). The product of the two PCR steps (size, $165 \mathrm{bp}$ ) was analyzed by electrophoresis on an $8 \%$ PAGE gel as described above.

DNA sequencing. The presence of K-ras mutations was confirmed by cycle sequencing. For this purpose, the mutated amplicons found by PCR RFLP and DEN-PCR were excised from a 3\% agarose gel and purified with the Qia Quick gel extraction kit (Qiagen) according to the manufacturer's recommendations. Sequencing reactions were then performed with the respective sequencing primer (5'-ACCTCTATTGTTGGA TCATA-3') and the 3'Big Dye Terminator Cycle Sequencing Ready Reaction kit (ABI, Weiterstadt, Germany) according to the manufacturer's instructions (14).

Statistical analysis. The mean age of patients and the respective standard deviation was calculated for all subgroups. In addition, the non-parametric Wilcoxon test was used to compare the age of the respective subgroups. The contingency $\chi^{2}$ test was applied to compare all other patient and tumor characteristics. P-values $<0.05$ were regarded as significant.

\section{Results}

The development of our new and more sensitive method depended on the selection of a suitable LNA clamp and the order of using enzymatic restriction and sealing the wild-type K-ras DNA with a clamp. In a first step, the oligonucleotide used for clamping was selected from a series of congeners with increasing ratio of LNA bases and therefore higher melting temperature. As shown in Fig. 1b the optimal effect was obtained with LNA No. 2 and 3, which sealed the K-ras wild-type effectively. Oligonucleotides with lower melting temperature failed to inhibit K-ras wild-type synthesis (data not shown), and that with higher melting temperature inhibited synthesis of mutated K-ras as well. Following selection of the optimal LNA-containing oligomers the order of using enzymatic digestion before or after LNA clamping was determined. It turned out that restriction with BstNI diminished the amplification of K-ras wild-type templates effectively. For better cost efficiency and practicability, the enzymatic digestion was selected as first step, followed by the clamping LNA-oligomer in the second PCR.

A limited series of experiments on the reliability and specificity of the method showed that all findings indicating a K-ras codon 12 mutation $(n=7)$ and those showing no K-ras codon 12 mutation $(n=9)$ could be repeated (data not shown).

DEN-PCR in comparison with the other described methods. To define the sensitivity of the DEN-PCR, dilutions of K-ras mutated SW620 colon carcinoma cells were prepared in K-ras wild-type SKW3 cells. The dilutions ranged from 1:10 to $1: 10^{7}$. The DEN PCR detected 1 mutated cell in $10^{7}$ wildtype cells and was thus by one log more sensitive than the PCR-RFLP with a sensitivity of $1: 10^{6}$ (Fig. 1c), and by several orders of magnitude more sensitive than the REMS-PCR and the real time PCR with PNA clamping that showed sensitivities of $1: 10^{2}$ and $1: 10^{3}$, respectively. Concerning the average time needed to perform an experiment, the DEN-PCR was completed within $8 \mathrm{~h}$, and thus considerably faster than the PCR-RFLP lasting about $48 \mathrm{~h}$, but slower than the REMS-PCR (4 h) and the real-time PCR (1.5 h).

Patient and tumor characteristics. The characteristics of all patients with colorectal tumors are given in Table I. The age of these patients ranged from 48 to 88 years. The mean age of male patients did not differ significantly from that of female patients.

Most of the tumors originated from the rectum and sigmoid of the large bowel (54.3 and 13.0\%) followed by tumors of the transverse colon $(10.9 \%)$, the ascending colon and cecum ( $8.7 \%$ each), and the descending colon (4.5\%). Out of 49 tumors, 46 were characterized histologically as adenocarcinomas, whereas the remaining three were adenomas. No gender related difference was detected regarding the site or histology of the tumors.

Most carcinomas were classified as tumor stages T2 $(50.0 \%)$ and T3 (34.8\%). Most tumors did not disseminate into regional lymph nodes (N0;65.2\%). The remaining tumors showed nodal involvement and were therefore classified as N1 (1-3 nodes positive; $19.6 \%$ ) and N2 (>3 nodes positive; $15.2 \%$ ). Distant metastasis (M1) was detected in $10.9 \%$ of all cases. No significant gender differences were observed.

According to the UICC status, most tumors were classified as UICC I (39.1\%), followed by UICC III, II and IV (26.1, 23.9 and $10.9 \%$ ). No residual tumor mass was found in most cases (R0; 91.3\%), the remaining patients with microscopic or macroscopic residual tumor disease were classified as R2 $(6.5 \%)$ or R1 $(2.2 \%)$.

Histopathologically, most tumors were graded as G2 (78.3\%) and G3 (19.6\%). Examination of the surrounding tumor tissue showed that only a minority of tumors (V1 $15.2 \%$ and V2 2.2\%) were diagnosed with venous vessels erosion, whereas a larger number of tumors $(95.7 \%)$ presented with lymphatic vessel invasion (L1).

Detection of K-ras mutations by four different methods. From using various K-ras detection methods, 26 of 46 carcinomas (57\%) and 1 of 3 adenomas (33.3\%) had mutations in K-ras codon 12. All these cases are shown in Table II, together with a complete list of the results of four different assays determining the K-ras mutation status, and the corresponding sequencing results.

From 27 K-ras codon 12 mutated tumors, 16 were found with all four methods, 2 with three methods and 9 only with PCR-RFLP and DEN-PCR. All samples were subjected to cycle sequencing. In 8 cases, the DEN-PCR product led to a sequencing result, whereas the respective fraction of mutated template from the PCR-RFLP was not sufficient for sequencing. The absence of confirmatory sequencing 
Table I. Patient and carcinoma characteristics specified by gender.

\begin{tabular}{|c|c|c|c|}
\hline & $\begin{array}{c}\text { Females } \\
(\%)\end{array}$ & $\begin{array}{c}\text { Males } \\
(\%)\end{array}$ & $\begin{array}{c}\text { Total } \\
(\%)\end{array}$ \\
\hline \multicolumn{4}{|l|}{ Patients } \\
\hline Number & $23(50)$ & $23(50)^{\mathrm{a}}$ & $46(100)$ \\
\hline Average age (years) & 70.4 & 72.6 & 71.5 \\
\hline \multicolumn{4}{|l|}{ Colorectal segment } \\
\hline Cecum & $3(13.0)$ & $1(4.3)$ & $4(8.7)$ \\
\hline Ascending colon & $1(4.3)$ & $3(13.0)$ & $4(8.7)$ \\
\hline Transverse colon & $4(17.3)$ & $1(4.3)$ & $5(10.9)$ \\
\hline Descending colon & 0 & $2(8.7)$ & $2(4.3)$ \\
\hline Sigmoid & $2(8.7)$ & $4(17.4)$ & $6(13.0)$ \\
\hline Rectum & $13(56.5)$ & $12(52.2)$ & $25(54.3)$ \\
\hline \multicolumn{4}{|l|}{ pTNM classification } \\
\hline $\mathrm{T} 1$ & 0 & $3(13.0)$ & $3(6.5)$ \\
\hline $\mathrm{T} 2$ & $10(43.5)$ & $13(56.5)$ & $23(50.0)$ \\
\hline T3 & $11(47.8)$ & $5(21.7)$ & $16(34.8)$ \\
\hline $\mathrm{T} 4$ & $2(8.7)$ & $2(8.7)$ & $4(8.7)$ \\
\hline No & $15(65.2)$ & $15(65.2)$ & $30(65.2)$ \\
\hline N1 & $5(21.7)$ & $4(17.4)$ & 9 (19.6) \\
\hline $\mathrm{N} 2$ & $3(13.0)$ & $4(17.4)$ & $7(15.2)$ \\
\hline M0 & $21(91.3)$ & $20(87.0)$ & $41(89.1)$ \\
\hline M1 & $2(8.7)$ & $3(13.0)$ & $5(10.9)$ \\
\hline \multicolumn{4}{|l|}{ UICC } \\
\hline I & $7(30.4)$ & $11(47.8)$ & $18(39.1)$ \\
\hline II & $8(34.8)$ & $3(13.0)$ & $11(23.9)$ \\
\hline III & $6(26.1)$ & $6(26.1)$ & $12(26.1)$ \\
\hline IV & $2(8.7)$ & $3(13.0)$ & $5(10.9)$ \\
\hline \multicolumn{4}{|l|}{ Histopathology } \\
\hline G1 & 0 & $1(4.3)$ & $1(2.2)$ \\
\hline $\mathrm{G} 2$ & $19(82.6)$ & $17(73.9)$ & $36(78.3)$ \\
\hline G3 & $4(17.4)$ & $5(21.7)$ & $9(19.6)$ \\
\hline G4 & 0 & 0 & 0 \\
\hline L0 & 0 & $2(8.7)$ & $2(4.3)$ \\
\hline L1 & 23 & $21(91.3)$ & $44(95.7)$ \\
\hline V0 & $20(87.0)$ & $18(78.3)$ & $38(82.6)$ \\
\hline V1 & $3(13.0)$ & $4(17.4)$ & $7(15.2)$ \\
\hline $\mathrm{V} 2$ & 0 & $1(4.3)$ & $1(2.2)$ \\
\hline R0 & $21(91.3)$ & $21(91.3)$ & $42(91.3)$ \\
\hline $\mathrm{R} 1$ & 0 & $1(4.3)$ & $1(2.2)$ \\
\hline $\mathrm{R} 2$ & $2(8.7)$ & $1(4.3)$ & $3(6.5)$ \\
\hline
\end{tabular}

${ }^{a}$ Three male patients were evaluated additionally, one patient with an adenoma of the ascending colon, as well as two patients with diverticulitis in sigma and rectum, respectively.

results (gold standard) was reason to neglect a weakly positive result of a K-ras screening assay. Based on this evaluation the DEN-PCR made a difference in 9 of 27 cases (33.3\%; $\mathrm{p}=0.001$ vs. RFLP), and thus was superior to the other methods used ( $<<0.002$; Fig. 2$)$.

The DEN-PCR showed a mutation after the first PCR step in 19 cases, which presumably have a ratio of $\mathrm{K}$-ras mutated to wild-type alleles in the range of $1: 10^{\circ}-1: 10^{2}$. As an example,

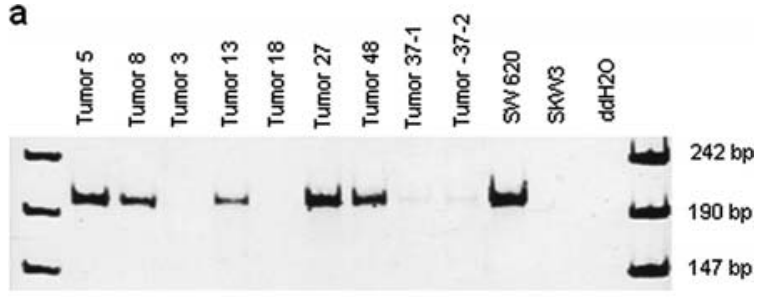

b
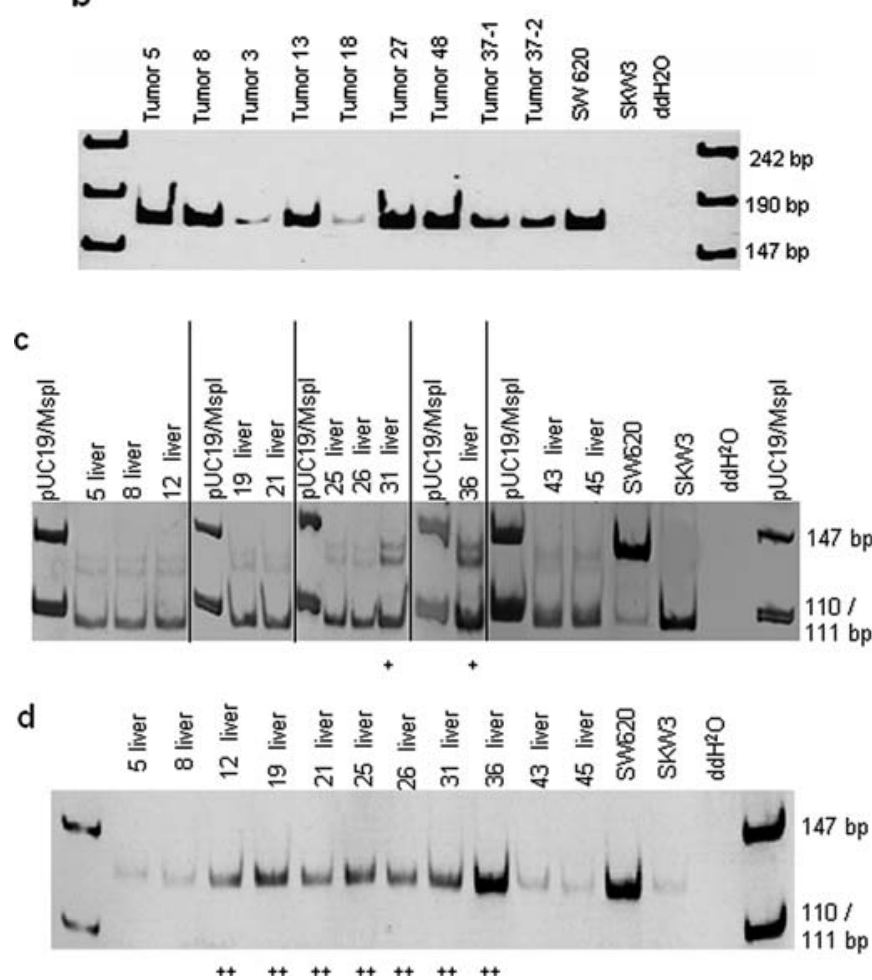

Figure 2. Comparison of DEN-PCR step I and II sensitivities. (a) After DEN-PCR step I five of nine tumors show a mutated band in K-ras codon 12 . (b) After DEN-PCR step II all nine tumors show a mutated band in K-ras codon 12. (c and d) Comparison of the sensitivities of PCR-RFLP and DEN-PCR. (c) Eleven liver biopsy samples were analyzed for K-ras codon 12 mutations by PCR-RFLP. Two of eleven liver biopsy samples show a week band (indicated with + ). After sequencing, the mutation in K-ras codon 12 could not been confirmed. (d) Analysis of the same liver biopsy samples by DEN-PCR. Seven of eleven liver biopsy samples show a positive band after performing DEN-PCR (marked by ++ ). After sequencing, all of these samples showed a mutation in K-ras codon 12 .

a subgroup of 5 primary tumors is shown in Fig. 2a. Eight of 27 primary tumours were found mutated after the second PCR step only, and therefore presumably contain K-ras mutated alleles at a frequency of $1: 10^{3}-1: 10^{7}$. Four of these 8 primary tumours are shown as an example in Fig. 2 b.

Twenty-seven tumors contained 31 mutations. The most common mutation was GGT $\rightarrow$ GTT followed by GGT $\rightarrow$ GAT and GGT $\rightarrow$ AGT.

Detection of K-ras mutations in patient tissues. A synopsis of all patients with K-ras mutated colorectal carcinoma and K-ras mutations indicating disseminated tumor cells in tissues other than the primary tumors is given in Table III. These 12 patients $(46.2 \%)$ of 27 patients with K-ras mutated tumor harbored 27 K-ras mutations, 19 (70.4\%) of which 
Table II. Comparison of method sensitivity in K-ras codon 12 mutated colorectal carcinomas.

\begin{tabular}{|c|c|c|c|c|c|c|c|}
\hline Patient no. & Localization & Gender & REMS & Real-time + PNA & RFLP & DEN-PCR & Sequencing (wt: GGT) \\
\hline 5 & Rectum & Male & ++ & ++ & +++ & $+++^{b}$ & GTT \\
\hline 8 & Rectum & Female & ++ & ++ & +++ & $+++^{\mathrm{b}}$ & GTT \\
\hline 12 & Transverse colon & Female & ++ & ++ & +++ & $+++^{\mathrm{b}}$ & GAT \\
\hline 17 & Rectum & Male & ++ & ++ & +++ & $+++^{\mathrm{b}}$ & GTT \\
\hline 19 & Rectum & Male & ++ & ++ & +++ & $+++^{\mathrm{b}}$ & GTT \\
\hline 21 & Sigma & Male & ++ & ++ & +++ & $+++^{\mathrm{b}}$ & GTT/GAT ${ }^{\mathrm{e}}$ \\
\hline 25 & Sigma & Male & ++ & ++ & +++ & $+++^{\mathrm{b}}$ & $\mathrm{GAT} / \mathrm{AGT}^{\mathrm{e}}$ \\
\hline 26 & Descending colon & Male & ++ & ++ & +++ & $+++^{b}$ & AGT \\
\hline 31 & Sigma & Male & ++ & ++ & +++ & $+++^{b}$ & GCT \\
\hline 36 & Rectum & Female & ++ & ++ & +++ & $+++^{\mathrm{b}}$ & GAT \\
\hline 38 & Ascending colon & Male & ++ & ++ & +++ & $+++^{b}$ & AGT \\
\hline 42 & Ascending colon ${ }^{\mathrm{a}}$ & Male & ++ & ++ & +++ & $+++^{b}$ & TGT \\
\hline 43 & Rectum & Male & ++ & ++ & +++ & $+++^{\mathrm{b}}$ & GTT \\
\hline 45 & Transverse colon & Male & ++ & ++ & +++ & $+++^{\mathrm{b}}$ & GAT \\
\hline 49 & Transverse colon & Female & ++ & ++ & +++ & $+++^{b}$ & GTT \\
\hline 37 & Rectum & Male & ++ & + & ++ & $+++^{b}$ & $\mathrm{AGT} / \mathrm{GAT}^{\mathrm{d}, \mathrm{e}}$ \\
\hline 27 & Cecum & Female & ++ & - & ++ & $+++^{b}$ & TGT/AGTe \\
\hline 13 & Sigma & Female & - & - & ++ & $+++^{\mathrm{b}}$ & GTT \\
\hline 48 & Rectum & Male & - & + & + & $+++^{b}$ & GAT \\
\hline 3 & Rectum & Female & - & - & + & $++^{\mathrm{c}}$ & GTT \\
\hline 6 & Rectum & Female & - & - & + & $++^{\mathrm{c}}$ & $\mathrm{AGT}^{\mathrm{d}}$ \\
\hline 7 & Rectum & Male & - & - & + & $++^{\mathrm{c}}$ & $\mathrm{GAT}^{\mathrm{d}}$ \\
\hline 15 & Rectum & Male & - & - & + & $++^{\mathrm{c}}$ & $\mathrm{GTT}^{\mathrm{d}}$ \\
\hline 18 & Rectum & Female & - & - & + & $++^{\mathrm{c}}$ & $\mathrm{GTT}^{\mathrm{d}}$ \\
\hline 24 & Ascending colon & Male & - & - & + & $++^{\mathrm{c}}$ & $\mathrm{GTT}^{\mathrm{d}}$ \\
\hline 28 & Transverse colon & Female & - & - & + & $++^{\mathrm{c}}$ & AGT/GAT ${ }^{\mathrm{d}, \mathrm{e}}$ \\
\hline 34 & Sigmoid & Male & - & - & + & $++^{\mathrm{c}}$ & $\mathrm{GTT} \mathrm{GCT}^{\mathrm{d}, \mathrm{e}}$ \\
\hline
\end{tabular}

${ }^{a}$ Adenoma; ${ }^{b}$ tissue found mutated after PCR I, corresponding to a ratio of mutated to wild-type cells ranging from $1: 10^{0}$ to $1: 10^{2}$. ${ }^{c}$ Tissue found mutated after PCR II, corresponding to a ratio of mutated to wild-type ranging from 1:10 ${ }^{3}$ to $1: 10^{7}$. ${ }^{\mathrm{d}}$ Sequence of the DEN-PCR product whereas the respective fraction of mutated template from PCR-RFLP was not sufficient for sequencing. ${ }^{\mathrm{e}}$ More than one mutation detected, the largest fraction is listed first. -, no K-ras mutated product; +, K-ras mutated product barely visible and could not be sequenced, ++ K-ras mutated product visible and could be sequenced; +++, K-ras mutated product clearly visible and could be sequenced.

Table III. List of patients with K-ras codon 12 mutated tissues.

\begin{tabular}{|c|c|c|c|c|c|c|c|c|c|c|c|c|c|c|c|c|}
\hline \multirow{2}{*}{\multicolumn{3}{|c|}{ Patient }} & \multirow{2}{*}{\multicolumn{8}{|c|}{ Histopathological staging }} & \multicolumn{5}{|c|}{$\mathrm{K}$-ras codon 12 sequencing results of patient tissues } & \multirow{3}{*}{$\begin{array}{c}\text { Influence on } \\
\mathrm{N} \text { - and M-statu }\end{array}$} \\
\hline & & & & & & & & & & & \multirow[b]{2}{*}{ Tumor $^{\mathrm{a}}$} & \multicolumn{2}{|r|}{ Liver } & \multirow[b]{2}{*}{ Lymph node } & \multirow[b]{2}{*}{$\mathrm{BM}$} & \\
\hline No. & Gender & Age & $\mathrm{T}$ & $\mathrm{N}$ & M & G & $\mathrm{R}$ & $\mathrm{L}$ & $\mathrm{V}$ & UICC & & Left lobe & Right lobe & & & \\
\hline 12 & Female & 79 & 4 & 2 & 1 & 2 & 2 & 1 & 1 & IV & GAT & $\mathrm{wt}^{\mathrm{b}}$ & wt & GAT & wt & - \\
\hline 17 & Male & 74 & 3 & 2 & 1 & 2 & 2 & 1 & 0 & IV & GTT & GTT & wt & GTT & wt & $-d$ \\
\hline 19 & Male & 50 & 3 & 0 & 0 & 2 & 0 & 1 & 0 & II & GTT & wt & wt & GTT & wt & $\mathrm{N} 0 \rightarrow \mathrm{N} 1 \mathrm{~mol}^{\mathrm{e}}$ \\
\hline 21 & Male & 78 & 2 & 0 & 0 & 2 & 0 & 1 & 0 & I & $\mathrm{GTT} / \mathrm{GAT}^{\mathrm{c}}$ & $\mathrm{GAT} / \mathrm{AGT}^{\mathrm{c}, \mathrm{f}}$ & wt & GAT/AGT ${ }^{\mathrm{c}}$ & wt & $\mathrm{M} 0 \rightarrow \mathrm{M} 1 \mathrm{~mol}$ \\
\hline 25 & Male & 69 & 2 & 0 & 0 & 2 & 0 & 0 & 0 & I & GAT/AGT & wt & $\mathrm{AGT}^{\mathrm{f}}$ & AGT & GTT/GAT $^{\mathrm{c}}$ & $\mathrm{M} 0 \rightarrow \mathrm{M} 1 \mathrm{~mol}$ \\
\hline 26 & Male & 82 & 3 & 2 & 0 & 2 & 0 & 1 & 0 & III & AGT & wt & GAT/AGT ${ }^{f}$ & AGT & wt & $\mathrm{M} 0 \rightarrow \mathrm{M} 1 \mathrm{~mol}$ \\
\hline 27 & Female & 66 & 3 & 1 & 0 & 2 & 0 & 1 & 1 & III & TGT/AGT ${ }^{\mathrm{c}}$ & wt & wt & AGT & $\mathrm{GCT}^{\mathrm{g}}$ & $\mathrm{M} 0 \rightarrow \mathrm{M} 1 \mathrm{~mol}$ \\
\hline 31 & Male & 63 & 2 & 2 & 0 & 2 & 0 & 1 & 0 & III & GCT & wt & GCT/AGT ${ }^{\mathrm{f}}$ & wt & wt & $\mathrm{M} 0 \rightarrow \mathrm{M} 1 \mathrm{~mol}$ \\
\hline 34 & Male & 78 & 2 & 0 & 0 & 2 & 0 & 1 & 0 & I & GTT/GCT ${ }^{\mathrm{c}}$ & wt & wt & wt & GCT & $\mathrm{M} 0 \rightarrow \mathrm{M} 1 \mathrm{~mol}$ \\
\hline 36 & Female & 63 & 4 & 0 & 0 & 2 & 0 & 1 & 0 & II & GAT & GAT $^{\mathrm{g}}$ & wt & wt & GAT & $\mathrm{M} 0 \rightarrow \mathrm{M} 1 \mathrm{~mol}$ \\
\hline 37 & Male & 75 & 2 & 0 & 0 & 2 & 0 & 1 & 0 & I & AGT/GAT ${ }^{\mathrm{c}}$ & wt & $\mathrm{AG}^{\mathrm{f}}$ & wt & wt & $\mathrm{M} 0 \rightarrow \mathrm{M} 1 \mathrm{~mol}$ \\
\hline 38 & Male & 70 & 1 & 0 & 0 & 1 & 0 & 0 & 0 & I & $\mathrm{AGT}^{\mathrm{c}}$ & $\mathrm{AGT} / \mathrm{GAT}^{\mathrm{c}, \mathrm{f}}$ & wt & GAT/AGT ${ }^{c}$ & wt & $\mathrm{M} 0 \rightarrow \mathrm{M} 1 \mathrm{~mol}$ \\
\hline
\end{tabular}

${ }^{a}$ Sequence obtained from both, PCR-RFLP and DEN-PCR-products; ${ }^{b} \mathrm{wt}$, wild-type sequence (GGT); ${ }^{c}$ tumor tissue contained two mutations; the more prevalent mutation is indicated first; ${ }^{\mathrm{d}}$ additional liver metastasis was also mutated in K-ras codon 12 and had the sequencing result: GTT. ${ }^{\mathrm{e}}$ On the left side, status from histopathology, on the right side, status suggested by matching mutations detected in the primary CRC and the apparently normal organ mol, molecular detection of disseminated tumor cells (TNM). ${ }^{\mathrm{f}}$ Sequence of the DEN-PCR product; ${ }^{\mathrm{g}}$ questionable relation between the mutations detected in the primary CRC and the apparently normal bone marrow because of dissenting mutations. 
Table IVA. Detection of disseminated tumor cells listed for all tumor stages.

\begin{tabular}{|c|c|c|c|c|c|c|c|}
\hline \multirow[b]{2}{*}{ Stage } & \multirow{2}{*}{$\begin{array}{l}\text { No. of all } \\
\text { patients }\end{array}$} & \multirow{2}{*}{$\begin{array}{c}\text { No. of patients } \\
\text { with K-ras mutated } \\
\text { primary tumor }\end{array}$} & \multirow[b]{2}{*}{ Liver $(\%)$} & \multicolumn{2}{|c|}{ K-ras mutated tissue } & \multirow[b]{2}{*}{ Any organ (\%) } & \multirow{2}{*}{$\begin{array}{c}\% \text { of K-ras } \\
\text { mutated patients }\end{array}$} \\
\hline & & & & Lymph node (\%) & Bone marrow $(\%)$ & & \\
\hline I & 18 & 12 & $4(22)$ & $3(16.7)$ & $2(11)$ & $5(27.8)$ & 41.7 \\
\hline II & 11 & 6 & $1(9.1)$ & $1(9.1)$ & $1(9.1)$ & $2(18.2)$ & 33 \\
\hline III & 12 & 6 & $2(16.7)$ & $2(16.7)$ & $1(8.9)$ & $3(25)$ & 50 \\
\hline IV & 5 & 2 & $1(20)$ & $2(40)$ & 0 & $2(40)$ & 100 \\
\hline Total & 46 & 26 & 8 & 8 & 4 & 12 & 46.2 \\
\hline
\end{tabular}

B, Detection of disseminated tumor cells listed for type of mutation and corresponding incidence.

\begin{tabular}{|c|c|c|c|c|c|c|c|}
\hline \multirow{2}{*}{$\begin{array}{l}\text { Type of } \\
\text { mutation }\end{array}$} & \multirow{2}{*}{$\begin{array}{c}\text { Frequency of } \\
\text { mutation in the } \\
\text { primary carcinoma }\end{array}$} & \multirow{2}{*}{$\begin{array}{l}\text { Patients } \\
\text { (organs) with DTC } \\
\text { corresponding to the } \\
\text { primary carcinoma }\end{array}$} & \multirow{2}{*}{$\begin{array}{c}\text { Patients } \\
\text { (organs) with DTC } \\
\text { not corresponding to } \\
\text { the primary carcinoma }\end{array}$} & \multicolumn{4}{|c|}{ Overview on organ sites } \\
\hline & & & & Liver & Lymph node & Bone marrow & Any organ \\
\hline All/any & $31^{\mathrm{a}}$ & $12^{\mathrm{b}}(19)$ & $6^{c}(8)$ & 12 & 10 & 5 & 27 \\
\hline GAT & 9 & $4(6)$ & $2(3)$ & 4 & 3 & 2 & 9 \\
\hline GTT & 13 & $2(3)$ & $1(1)$ & $1^{\mathrm{d}}$ & 2 & 1 & $4^{\mathrm{e}}$ \\
\hline AGT & 6 & $5(8)$ & $2(3)$ & $6 \mathrm{f}$ & $5^{\mathrm{g}}$ & 0 & 11 \\
\hline GCT & 2 & $2(2)$ & $1(1)$ & 1 & - & 2 & 3 \\
\hline TGT & 1 & $0(0)$ & $0(0)$ & - & - & - & 0 \\
\hline
\end{tabular}

${ }^{\text {aRelated to }} 26$ patients; ${ }^{b}$ DTC were detected in organs of 12 patients (Table III), one patient harboured 2 mutations in the primary carcinoma which both gave rise to DTC with corresponding mutations; ${ }^{\mathrm{c} s i x}$ of twelve patients who harboured DTC with mutations corresponding to the primary carcinoma also had DTC with mutations which did not match that of the primary carcinoma; ${ }^{\mathrm{d}} \mathrm{p}=0.034$, incidence of GTT significantly decreased vs. that in primary carcinoma; ${ }^{\mathrm{e}} \mathrm{p}=0.023$; incidence of GTT significantly decreased vs. that in primary carcinoma; ${ }_{\mathrm{p}}^{\mathrm{f}}=0.044$; incidence of AGT significantly increased vs. that in primary carcinoma; ${ }^{\mathrm{g}} \mathrm{p}=0.057$; incidence of AGT increased vs. that in primary carcinoma.

were identical to that of the primary, whereas $8(29.6 \%)$ were different. Only one of these 8 mutations was not detected in conjunction with a mutation that was found in the primary carcinoma. Twelve of these 27 mutations were found in the liver, 10 in lymph node tissue, and 5 in bone marrow. Based on potential target tissues of metastasis, K-ras mutations were detected in the liver and lymph node tissues of 8 patients, and in bone marrow of 4 patients. Only 1 patient harbored K-ras mutations in all these three tissues, 2 tissues were positive for K-ras mutated disseminated tumor cells in 6 patients, and 1 tissue was positive in 5 patients. All of these mutations were detected only by the second PCR-step, thus indicating a ratio of disseminated tumor to normal cells lower than $1: 10^{2}$ (Fig. 2c and d). Remarkably, the information on the presence of DTC in liver, lymph node and bone marrow tissue would have influenced the $\mathrm{N}$ and $\mathrm{M}$ status in 10 of these 12 patients.

Table IVA gives a summary of the presence of DTC relative to tumor stages. Up to $50 \%$ of patients with K-ras mutated primary colorectal carcinoma at stages I-III (local disease) carried K-ras mutated DTC in liver, lymph node or bone marrow tissues. Remarkably, liver biopsies were as frequently involved as lymph node specimen and prevailed over bone marrow tissues.
Twelve of 26 patients with K-ras mutations in their primary carcinoma also carried DTC with matching K-ras mutations. Interestingly, 6 of these 12 patients also harbored a mutation that did not correspond to that found in the primary carcinoma (Table IVB). Of note, two types of K-ras mutations found in the primary carcinoma differed in frequency from the others with regard to their relative occurrence in DTC. The mutation GTT (Gly $\rightarrow$ Val) was found underrepresented in DTC $(p=0.023)$, whereas the mutation AGT $($ Gly $\rightarrow$ Ser $)$ was overrepresented $(\mathrm{p} \leq 0.05)$.

\section{Discussion}

In the present prospective study we introduce a highly sensitive detection method for K-ras codon 12 mutations consisting of two consecutive steps: after restriction enzyme digestion of wild-type K-ras templates in the first PCR step, LNA clamping oligomers are used to inhibit any remaining K-ras wild-type amplification in the second PCR step. The resulting template is a single band containing the K-ras mutation in a purity that allows direct sequencing after a simple PCR clean-up step. This double enriched nested-PCR yields a sensitivity significantly superior to other available methods $(\mathrm{p}=0.01)$ and is suited for both 
detection of K-ras codon 12 mutations in primary colorectal cancers and for identifying disseminated tumor cells by their $\mathrm{K}$-ras codon 12 mutation. This diagnostic tool is limited by obtaining a qualitative result and not a quantification of the extent of mutant cell involvement. Nevertheless, its value is shown by the following considerations. According to a literature survey about $30-50 \%$ of all patients with colorectal carcinoma harbor a K-ras codon 12 mutation in their primary tumor $(20,23-25)$. In fact, with the increased sensitivity of the DEN-PCR method, we found a higher incidence of K-ras codon 12 mutations in tumor tissues (58 instead of $35 \%, \mathrm{p}=0.03$ ). Because soon the method may be supplemented with a parallel screen for K-ras codon 13 mutations, it can be expected that the percentage of colorectal carcinomas detected to harbor a K-ras mutation will still increase. In addition, the respective mutation of K-ras codon 12 can be used as marker of DTC in samples from organs potentially affected by metastasis. In this regard, we hypothesize that the detection of K-ras mutations is by far more specific than that of e.g. epithelial markers (26). The relevance of this aspect is demonstrated by diagnosing around $25-30 \%$ of all colorectal cancer patients as UICC stage II patients. Of note, about $20-30 \%$ of these patients will show recurrent disease, despite successful R0 resection and it is very likely that these patients have undergone tumor cell dissemination before the resection of their primary carcinoma. In fact, 2 of 6 CRC stage II and 3 of 6 CRC stage III patients were positive for DTC in at least one organ investigated. It is tempting to speculate, which degree of overlap will occur between these DTC positive patients and those who will show recurrent disease, a correlation that is to be assessed by follow-up studies. In a preceding study, a correlation was found between the presence of DTC in liver biopsies, determined by a PCR-RFLP detecting K-ras mutations, and subsequent survival. Patients harboring DTC in their liver showed a significantly reduced probability of survival than their DTC negative counterparts (27). It is furthermore remarkable that the percentage of DTC-positive colorectal cancer cases in stage $\mathrm{I}$ is indistinguishable from those in stages II and III indicating start of tumor cell dissemination very early in tumor progression. Certainly, future studies with larger patient numbers will have to corroborate this observation. Tumor cell dissemination was found to a similar extent in liver and lymph node tissues ( $31 \%$ of patients with K-ras mutated primary CRC) and to a lesser degree in bone marrow (15\%). The detection of K-ras mutated DTC in bone marrow is due to the more sensitive DEN-PCR, whereas other methods, including PCR-RFLP failed to reliably detect K-ras mutations in this organ.

The relative frequency of DTC in liver tissue resembles that of the initial results with the established PCR-RFLP method (34\%) (14). Subsequent studies with the same method but a polymerase producing higher background, and thus obscuring faint bands, detected a reduced rate of DTC (12\%) in liver biopsies of CRC cases (8). In this study, again, a higher frequency was found in liver biopsies (31\%) indicating increased sensitivity for detecting DTC by DEN-PCR as compared to PCR-RFLP ( $p=0.035)$. Whether or not the inclusion of these patients will contribute to a better estimation of prognosis remains to be determined.
The spectrum of mutations found with the DEN-PCR is similar to that seen before (14). Transversion mutations [GGT $\rightarrow$ GTT/Val $(13 / 31,41.9 \%) ;$ TGT/Cys $(2 / 31,6.5 \%)$; GCT/Ala $(1 / 31,3.2 \%)]$ prevailed over transition mutations [GGT $\rightarrow$ GAT/Asp (9/31, 29.0\%); AGT/Ser (6/31, 19.4\%)] and the substitution of $\mathrm{G}$ by $\mathrm{T}(15 / 31,48.4 \%)$ or $\mathrm{A}(15 / 31$, $48.4 \%$ ) was predominant ( $97 \%$ of all mutations), with the second base being altered more often than the first base (22 vs. 8 mutations).

Analyses of the prognostic impact of certain mutations have been equivocal. Based on an early meta-analysis of published data, Andreyev et al concluded that K-ras mutations correlated with poor outcome in CRC-patients (28). A more recent meta-analysis involving 4268 patients from 42 different institutions, however, concluded that only $\mathrm{G} \rightarrow \mathrm{T}$ transversion mutations at codon 12 were correlated with an adverse outcome (20). This analysis did not include a follow-up of the patients. However, if matching mutations only are considered and if there are different frequencies of a given mutation between DTC and the primary carcinomas, an overrepresentation among DTC could be regarded as indicative of a mutation with a 'high penetrance' whereas an under-representation would correspond to a mutation with a 'low penetrance'. According to this consideration, GTT was found to be a mutation with a low penetrance whereas AGT was associated with high penetrance. Whether or not these differences translate into a more aggressive metastasis formation of the latter compared to the former remains to be verified in follow-up studies.

Regardless of the question whether or not K-ras mutations in the primary CRC could be predictive of a poor prognosis, the approach of detecting DTC specifically by their K-ras mutation is independent from this relationship and detection of DTC could well be a prognostic parameter of its own. This hypothesis is supported by our previous finding associating K-ras codon 13 mutations with lymph node involvement, and codon 12 mutations with dissemination into the liver $(18,19)$.

Having established a sensitive detection method, the question arises whether or not the subgroup of patients with DTC identified by a matching K-ras codon 12 mutation could be treated. This idea would be worthwhile to follow if an overlap existed between the patients with K-ras codon 12 positive DTC and those with subsequent recurrence. Information on the K-ras status of a tumor or its DTC will also be valuable if e.g. treatment with EGF-receptor targeted therapies (antibodies like cetuximab or tyrosine kinase inhibitors such as gefitinib or erlotinib) was envisaged. It is known that mutations in K-ras impair EGF-receptor targeted therapy effects, due to the continued signaling of K-ras which results in circumventing the blocked EGF-receptor $(29,30)$. In line with this chain of effects experience from treating colorectal cancer patients with cetuximab, an antibody against the EGF-receptor, has shown that K-ras mutations are an independent prognostic factor for the success of this treatment $(31,32)$. Therefore, the DEN-PCR assay described in this study may well prove vital not only for detecting trace amounts of K-ras codon 12 mutations but also for predicting response to EGF-receptor targeted therapies. Thus, in any case, on the way to an individual 
therapy for any colorectal carcinoma patient, DEN-PCR could contribute to assist in individualizing the colorectal carcinoma therapy.

In conclusion, the new DEN-PCR is a sensitive and fast PCR-method for finding K-ras codon 12 mutations in organs of potential metastasis, especially in liver and lymph node biopsies and in tissues such as bone marrow samples. For patients harboring K-ras mutations in their primary carcinoma, it could well contribute to distinguish colorectal carcinoma patients who could benefit from adjuvant therapy from those who would only have to tolerate adverse effects.

\section{References}

1. Parkin DM, Bray F, Ferlay J and Pisani P: Global cancer statistics 2002. CA Cancer J Clin 55: 74-108, 2005.

2. Jemal A, Tiwari RC, Murray T, et al: Cancer statistics, 2004. CA Cancer J Clin 54: 8-29, 2004.

3. Jemal A, Siegel R, Ward E, Murray T, Xu J and Thun MJ Cancer statistics, 2007. CA Cancer J Clin 57: 43-66, 2007.

4. Benson AB III, Schrag D, Somerfield MR, et al: American Society of Clinical Oncology recommendations on adjuvant chemotherapy for stage II colon cancer. J Clin Oncol 22: 3408-3419, 2004.

5. Conzelmann M, Linnemann U and Berger MR: Detection of disseminated tumour cells in the liver of colorectal cancer patients. Eur J Surg Oncol 31: 38-44, 2005.

6. Liefers GJ, Cleton-Jansen AM, Hermans J, van Krieken JH, Cornelisse CJ and Tollenaar RA: Micrometastases and survival in stage II colorectal cancer. N Engl J Med 339: 223-228, 1998 .

7. Gill S, Loprinzi CL, Sargent DJ, et al: Pooled analysis of fluorouracil-based adjuvant therapy for stage II and III colon cancer: who benefits and by how much? J Clin Oncol 22: 1797-1806, 2004.

8. Dieterle CP, Conzelmann M, Linnemann U and Berger MR: Detection of isolated tumor cells by polymerase chain reactionrestriction fragment length polymorphism for K-ras mutations in tissue samples of 199 colorectal cancer patients. Clin Cancer Res 10: 641-650, 2004.

9. Weitz J, Kienle P, Magener A, et al: Detection of disseminated colorectal cancer cells in lymph nodes, blood and bone marrow. Clin Cancer Res 5: 1830-1836, 1999.

10. Keller JW, Franklin JL, Graves-Deal R, Friedman DB, Whitwell CW and Coffey RJ: Oncogenic KRAS provides a uniquely powerful and variable oncogenic contribution among RAS family members in the colonic epithelium. J Cell Physiol 210: 740-749, 2007.

11. Fearon ER and Vogelstein B: A genetic model for colorectal tumorigenesis. Cell 61: 759-767, 1990.

12. Vogelstein B, Fearon ER, Hamilton SR, et al: Genetic alterations during colorectal-tumor development. N Engl J Med 319 : 525-532, 1988

13. Conzelmann M, Linnemann U and Berger MR: Detection of disseminated tumour cells in the liver of cancer patients. Eur J Surg Oncol 31: 977-985, 2005.

14. Schimanski CC, Linnemann U and Berger MR: Sensitive detection of K-ras mutations augments diagnosis of colorectal cancer metastases in the liver. Cancer Res 59: 5169-5175, 1999.

15. Tortola S, Steinert R, Hantschick M, et al: Discordance between $\mathrm{K}$-ras mutations in bone marrow micrometastases and the primary tumor in colorectal cancer. J Clin Oncol 19: 2837-2843, 2001.
16. Taback B, Bilchik AJ, Saha S, et al: Peptide nucleic acid clamp PCR: a novel K-ras mutation detection assay for colorectal cancer micrometastases in lymph nodes. Int J Cancer 111: 409-414, 2004

17. Bazan V, Migliavacca M, Zanna I, et al: Specific codon 13 $\mathrm{K}$-ras mutations are predictive of clinical outcome in colorectal cancer patients, whereas codon $12 \mathrm{~K}$-ras mutations are associated with mucinous histotype. Ann Oncol 13: 1438-1446, 2002.

18. Conzelmann M, Linnemann U and Berger MR: K-ras codon 12 and 13 mutations are correlated with differential patterns of tumor cell dissemination in colorectal cancer patients. Int J Oncol 24: 1537-1544, 2004

19. Kraus MC, Seelig MH, Linnemann U and Berger MR: The balanced induction of K-ras codon 12 and 13 mutations in mucosa differs from their ratio in neoplastic tissues. Int J Oncol 29: 957-964, 2006.

20. Andreyev HJ, Norman AR, Cunningham D, et al: Kirsten ras mutations in patients with colorectal cancer: the 'RASCAL II' study. Br J Cancer 85: 692-696, 2001.

21. Lahr G: PNA clamp technique for detecting a Ki-ras2 mutation using the LightCycler instrument. Biochemica 4: 14-16, 2002.

22. Ward R, Hawkins N, O'Grady R, et al: Restriction endonuclease-mediated selective polymerase chain reaction: a novel assay for the detection of K-ras mutations in clinical samples. Am J Pathol 153: 373-379, 1998

23. Calistri D, Rengucci C, Seymour I, et al: Mutation analysis of p53, K-ras, and BRAF genes in colorectal cancer progression. J Cell Physiol 204: 484-488, 2005.

24. Finkelstein SD, Sayegh R, Christensen S and Swalsky PA: Genotypic classification of colorectal adenocarcinoma. Biologic behavior correlates with K-ras-2 mutation type. Cancer 71: 3827-3838, 1993.

25. Finkelstein SD, Sayegh R, Bakker A and Swalsky P: Determination of tumor aggressiveness in colorectal cancer by K-ras-2 analysis. Arch Surg 128: 526-531, 1993.

26. Koch M, Kienle P, Logan E, et al: Detection of disseminated tumor cells in liver biopsies of colorectal cancer patients is not associated with a worse prognosis. Ann Surg Oncol 14: 810-817, 2007.

27. Linnemann U, Schimanski CC, Gebhardt C and Berger MR: Prognostic value of disseminated colorectal tumor cells in the liver: results of follow-up examinations. Int J Colorectal Dis 19: $380-386,2004$

28. Andreyev HJ, Norman AR, Cunningham D, Oates JR and Clarke PA: Kirsten ras mutations in patients with colorectal cancer: the multicenter 'RASCAL' study. J Natl Cancer Inst 90: 675-684, 1998

29. Toschi L and Cappuzzo F: Understanding the new genetics of responsiveness to epidermal growth factor receptor tyrosine kinase inhibitors. Oncologist 12: 211-220, 2007.

30. Uchida A, Hirano S, Kitao H, et al: Activation of downstream epidermal growth factor receptor (EGFR) signaling provides gefitinib-resistance in cells carrying EGFR mutation. Cancer Sci 98: 357-363, 2007

31. Khambata-Ford S, Garrett CR, Meropol NJ, et al: Expression of epiregulin and amphiregulin and K-ras mutation status predict disease control in metastatic colorectal cancer patients treated with cetuximab. J Clin Oncol 25: 3230-3237, 2007.

32. Lievre A, Bachet JB, Boige V, et al: KRAS mutationsas an independent prognostic factor in patients with advanced colorectal cancer treated with cetuximab. J Clin Oncol 26: 374-379, 2008 . 